\title{
A Systematic Review of SaCroiliac Joint Interventions
}

\author{
Anne Marie McKenzie-Brown, MD, Rinoo V. Shah, MD, Nalini Sehgal, MD, and Clifford R. Everett, MD \\ Background: The sacroiliac joint is an \\ accepted source of low back pain with or \\ without associated lower extremity symp- \\ toms. The diagnosis and management of \\ sacroiliac joint pain and the role of interven- \\ tional techniques have been controversial. \\ Objective: To evaluate the clinical use- \\ fulness of sacroiliac joint interventions in \\ the diagnosis and management of sacroili- \\ ac joint pain. \\ Study Design: A systematic review us- \\ ing the criteria as outlined by the Agency for \\ Healthcare Research and Quality (AHRQ), Co- \\ chrane Review Group Criteria, and QUADAS \\ criteria for diagnostic studies. \\ Methods: The databases of EMBASE \\ and MEDLINE (1966 to November 2004), and \\ Cochrane Review were searched. The search- \\ es included systematic reviews, narrative re- \\ views, prospective and retrospective studies, \\ and cross-references from articles reviewed \\ The search strategy included sacroiliac joint \\ pain and dysfunction, sacroiliac joint injec- \\ tions, interventions, and radiofrequency. \\ Results: The results of this systematic \\ evaluation showed that for diagnostic pur- \\ poses, there is moderate evidence showing \\ the accuracy of comparative, controlled lo- \\ cal anesthetic blocks. Prevalence of sacroili- \\ ac joint pain was demonstrated to be $10 \%$ to \\ $19 \%$ by a double block paradigm. The false- \\ positive rate of single, uncontrolled, sacroili- \\ ac joint injections was reported as $20 \%$. \\ For therapeutic purposes intraarticular \\ sacroiliac joint injections with steroid and \\ radiofrequency neurotomy were evaluat- \\ ed. Based on this review, there was moder- \\ ate evidence for short-term and limited evi- \\ dence for long-term relief with intraarticular \\ sacroiliac joint injections. Evidence for radio- \\ frequency neurotomy in managing sacroiliac \\ joint pain was limited or inconclusive. \\ Conclusions: The evidence for the \\ specificity and validity of diagnostic sacroil- \\ iac joint injections was moderate. \\ The evidence for therapeutic \\ intraarticular sacroiliac joint injections was \\ limited to moderate. \\ The evidence for radiofrequency neu- \\ rotomy in managing chronic sacroiliac joint \\ pain was limited. \\ Keywords: Low back pain, sacroiliac \\ joint pain, axial pain, spinal pain, diagnostic \\ block, and sacroiliac joint injection
}

Descriptions of the sacroiliac joint as a source of low back pain date back to the early 1900's. It was not until after 1934, when Mixter and Barr (1) described disc herniation as another source of pain in the lumbar spine, that it's prominence as a major source of back pain declined (24). Until recently, the evidence for the sacroiliac joint as a pain generator had been only empirical, derived from successful treatment of patients with sacroiliac joint pain with certain clinical symptoms and physical findings (5). The sacroiliac joint is unable to function in isolation; anatomically and biomechanically it

From Emory Department of Anesthesiology, Emory Center for Pain Medicine, Atlanta, GA , Texas Tech University, Lubbock, TX, University of Wisconsin Hospital \& Clinics, Madison, WI, and University of Rochester Medical Center, Rochester, NY.

Address Correspondence: Ann Marie McKenzieBrown, MD, Emory Center for Pain Medicine, 550 Peachtree Street, NE, Atlanta GA 30308

Disclaimer: Nothing of monetary value was received in the preparation of this manuscript. Conflict of Interest: None

Acknowledgement:

Manuscript received on 12/21/2004

Revision submitted on 01/07/2005

Accepted for publication on 01/09/2005 shares all of its muscles with the hip joint. Ligamentous structures and the muscles they support affect much of the stability of the sacroiliac joint. These include the very strong interosseous ligaments as well as the iliolumbar, sacrotuberous and sacrospinous ligaments. The result is very limited motion of the sacroiliac joint under normal circumstances. The sacroiliac joint is also closely associated with the piriformis, gluteus, erector spinae, and quadratus lumborum muscles $(4,6)$. Sacroiliac joint pain may be the result of direct trauma, unidirectional pelvic shear, repetitive and torsional forces. Chou et al (7), after looking retrospectively at 54 patients with sacroiliac joint pain, found that trauma $(44 \%)$ and cumulative or repetitive injury $(21 \%)$ were inciting events for the development of sacroiliac joint pain and that $35 \%$ of patients had idiopathic or spontaneous onset of their pain. Of those with idiopathic or spontaneous etiologies for their sacroiliac joint pain, greater than $50 \%$ of patients had prior lumbar surgery.

The sacroiliac joint is a diarthrodial joint. The sacroiliac joint receives innervation from the lumbosacral nerve roots
(8-13). Fortin et al (9), based on an anatomic study on adult cadavers, concluded that the sacroiliac joint is predominantly, if not entirely, innervated by sacral dorsal rami. Murata et al (8) illustrated that the sensory nerve fibers to the dorsal side of the sacroiliac joint were derived from the DRGs of the lower lumbar and sacral levels (from L4 to S2), and those to the ventral side from the DRGs of the upper lumbar, lower lumbar, and sacral levels (from L1 to S2). Vilensky et al (12) showed the presence of nerve fibers and mechanoreceptors in the sacroiliac ligament.

Referral patterns of sacroiliac joint provocation or irritation have been published. Fortin et al (14) successfully generated a pain referral map using provocative injections first of dye, then local anesthetic into the sacroiliac joint in 10 asymptomatic volunteers. Fortin et al (15) also evaluated the applicability of a pain referral map as a screening tool for sacroiliac joint dysfunction. In a retrospective study, Slipman et al (16) demonstrated sacroiliac joint pain referral zones. Schwarzer et al (17) found the only distinguishing pattern of the patients who responded to sacroiliac joint injections to be 
Table 1. Domains and elements for diagnostic studies developed by the Agency for Healthcare Research and Quality (AHRQ)

\begin{tabular}{|ll|}
\hline Domain" & Elements* \\
\hline Study Population & $\begin{array}{c}\text { - Subjects similar to populations in which the test would be used and with a similar spectrum } \\
\text { of disease }\end{array}$ \\
Adequate Description of Test & - Details of test and its administration sufficient to allow for replication of study \\
Appropriate Reference Standard & - Appropriate reference standard ("gold standard") used for comparison \\
Blinded Comparison of Test and Reference & - Independent, blind interpretation of test and reference \\
Avoidance of Verification Bias & - Decision to perform reference standard not dependent on results of test under study \\
\hline
\end{tabular}

"Key domains are in italics ${ }^{*}$ Elements appearing in italics are those with an empirical basis. Elements appearing in bold are those considered essential to give a system a Yes rating for the domain. Adapted from ref 39

groin pain $(\mathrm{p}<0.004)$.

The rationale for the use of sacroiliac joint blocks as the tool for the diagnosis of sacroiliac joint pain is based upon the fact that sacroiliac joints are richly innervated and have been shown to be capable of being a source of low back pain and referred pain in the lower extremity (8-17). There are no absolute historical, physical, or radiological features to provide definitive diagnosis of sacroiliac joint pain (1625). Nevertheless, Broadhurst and Bond (25) reported $77 \%$ to $87 \%$ sensitivity with three positive provocative sacroiliac joint maneuvers. Laslett et al (18) found that

when patients had three or more positive provocative sacroiliac tests, they were 28 times more likely to have significant pain relief following a diagnostic sacroiliac joint injection. Patients with pain above the L5 spinous process are less likely to have pain originating from the sacroiliac joint $(18,19,25)$. Thus, a corroborative history and physical examination can enter into the differential diagnosis of sacroiliac joint pain but cannot make a definitive diagnosis of sacroiliac joint syndrome $(26,27)$. In spite of reports of the efficacy of plain films $(21,28,29)$, computed tomography (22), single photon emission

Table 2. Items utilized for assessment of quality of individual articles of diagnostic studies by QUADAS tool

\begin{tabular}{|c|c|}
\hline Item & \\
\hline 1. & $\begin{array}{l}\text { Was the spectrum of patients representative of the patients who will receive the test } \\
\text { in practice? }\end{array}$ \\
\hline 2. & Were selection criteria clearly described? \\
\hline 3. & Is the reference standard likely to correctly classify the target condition? \\
\hline 4. & $\begin{array}{l}\text { Is the time period between reference standard and index test short enough to be } \\
\text { reasonably sure that the target condition did not change between the two tests? }\end{array}$ \\
\hline 5. & $\begin{array}{l}\text { Did the whole sample or a random selection of the sample, receive verification using } \\
\text { a reference standard of diagnosis? }\end{array}$ \\
\hline 6. & Did patients receive the same reference standard regardless of the index test result? \\
\hline 7. & $\begin{array}{l}\text { Was the reference standard independent of the index test(i.e. the index test did not } \\
\text { form part of the reference standard)? }\end{array}$ \\
\hline 8. & $\begin{array}{l}\text { Was the execution of the index test described in sufficient detail to permit } \\
\text { replication of the test? }\end{array}$ \\
\hline 9. & $\begin{array}{l}\text { Was the execution of the reference standard described in sufficient detail to permit } \\
\text { its replication? }\end{array}$ \\
\hline 10. & $\begin{array}{l}\text { Were the index test results interpreted without knowledge of the results of the } \\
\text { reference standard? }\end{array}$ \\
\hline 11. & $\begin{array}{l}\text { Were the reference standard results interpreted without knowledge of the results of } \\
\text { the index test? }\end{array}$ \\
\hline 12. & $\begin{array}{l}\text { Were the same clinical data available when test results were interpreted as would be } \\
\text { available when the test is used in practice? }\end{array}$ \\
\hline 13. & Were uninterpretable/intermediate test results reported? \\
\hline 14. & Were withdrawals from the study explained? \\
\hline
\end{tabular}

Adapted from ref 40 computed tomography (30), bone scans $(31,32)$, nuclear imaging (33-36), and magnetic resonance imaging (37) in delineating radiographic sacroiliac joint abnormalities, there are no definitive corroborative radiologic findings identified thus far in patients with sacroiliac joint syndrome $(5,27)$. Associations have been made between a history of prior spinal surgery and sacroiliac joint pain. Katz et al (38) retrospectively evaluated low back pain patients who had prior lumbosacral fusion and found that $32 \%$ to $61 \%$ of those patients possibly had sacroiliac joint pain. Diagnostic blocks of a sacroiliac joint can be performed in order to determine that the sacroiliac joint is the source of the patient's pain. The sacroiliac joint can be anesthetized with intraarticular injection of local anesthetic performed under fluoroscopy with confirmation of dye spread throughout the joint space. Similarly, intraarticular injections with steroid and radiofrequency neurotomy have been employed to manage chronic sacroiliac joint pain as therapeutic interventional techniques. However, there has been no systematic evaluation of the evidence of diagnostic sacroiliac joint injections or therapeutic sacroiliac joint injections. Hence this systematic review was undertaken to assess the level of evidence for diagnostic sacroiliac joint blocks and therapeutic sacroiliac joint interventions involving intraarticular injections and radiofrequency neurotomy.

\section{Search Strategy}

The databases of EMBASE (1966 - November 2004), PubMed/MEDLINE (1966 to November 2004), and MD Consult were searched. A Cochrane Database search was performed. The searches included systematic reviews, narrative re- 
Table 3. AHRQ's key domains and elements for systems to rate quality of randomized controlled trials

\begin{tabular}{|c|c|}
\hline Domain ${ }^{\star}$ & Elements $^{\#}$ \\
\hline Study Question & - Clearly focused and appropriate question \\
\hline \multirow[t]{3}{*}{ Study Population } & - Description of study population \\
\hline & - Specific inclusion and exclusion criteria \\
\hline & - Sample size justification \\
\hline \multirow[t]{3}{*}{ Randomization } & - Adequate approach to sequence generation \\
\hline & - Adequate concealment method used \\
\hline & - Similarity of groups at baseline \\
\hline Blinding & $\begin{array}{l}\text { - Double-blinding (e.g., of investigators, caregivers, subjects, assessors, and other key study personnel as } \\
\text { appropriate) to treatment allocation }\end{array}$ \\
\hline \multirow[t]{3}{*}{ Interventions } & $\begin{array}{l}\text { - Intervention(s) clearly detailed for all study groups (e.g., dose, route, timing for drugs, and details sufficient for } \\
\text { assessment and reproducibility for other types of interventions) }\end{array}$ \\
\hline & - Compliance with intervention \\
\hline & - Equal treatment of groups except for intervention \\
\hline \multirow[t]{2}{*}{ Outcomes } & - Primary and secondary outcome measures specified \\
\hline & - Assessment method standard, valid, and reliable \\
\hline \multirow[t]{4}{*}{ Statistical Analysis } & $\begin{array}{l}\text { - Appropriate analytic techniques that address study withdrawals, loss to follow-up, missing data, and intention } \\
\text { to treat }\end{array}$ \\
\hline & - Power calculation \\
\hline & - Assessment of confounding \\
\hline & - Assessment of heterogeneity, if applicable \\
\hline \multirow[t]{2}{*}{ Results } & - Measure of effect for outcomes and appropriate measure of precision \\
\hline & - Proportion of eligible subjects recruited into study and followed up at each assessment \\
\hline Discussion & - Conclusions supported by results with possible biases and limitations taken into consideration \\
\hline Funding or Sponsorship & - Type and sources of support for study \\
\hline
\end{tabular}

${ }^{\star}$ Key domains are in italics \#Elements appearing in italics are those with an empirical basis. Elements appearing in bold are those considered essential to give a system a Yes rating for the domain. Adapted from ref 39

views, prospective and retrospective studies and cross-references from articles reviewed, the search strategy included sacroiliac joint pain and dysfunction, sacroiliac joint injections, and sacroiliac joint radiofrequency. One reviewer assessed the quality of the articles for inclusion. Three reviewers evaluated the studies. A list was generated of the abstracts reviewed. If there were no clear exclusion criteria within the abstract then the full article was reviewed. Those articles were then outlined for their study population, outcome and quality.

\section{Inclusion Criteria}

\section{Types of studies}

Study designs that used controlled and uncontrolled studies of sacroiliac joint injections were included.

\section{Types of participants}

Subjects with low back pain with or without leg pain for at least 3 months; participants had tried and failed conservative management; pain sufficient to be referred to a pain specialist/spinal injectionist for the diagnostic injection. Prior radiographic imaging excluding an anatomic cause for the patient's symptoms.

\section{Types of interventions}

Local anesthetic injections; placebo controlled injections; double injections with a screening lidocaine sacroiliac joint injection followed by a bupivacaine confirmatory injection; sacroiliac joint injections with local anesthetic and steroid; and radiofrequency neurotomy.

\section{Types of Outcome measures}

Pain relief was the main outcome measured. The pain relief had to be at least $50 \%$.

\section{Exclusion criteria}

Types of studies

Case reports; descriptive reports

\section{Types of participants}

Participants with pain symptoms for $<3$ months; sacroiliac joint injections performed on animals.

\section{Types of interventions}

Single injections; non-fluoroscopic /non-radiographically guided injections, surgical interventions (fusions, fixations)

\section{Methodological Quality}

Methodological quality of articles was assessed by the criteria established by AHRQ (39), criteria described for QUADAS (40), and Cochrane Review Group for randomized trials (41). The details of application of these criteria are illustrated in Tables 1 to 5. Inclusion and exclusion criteria were used as described elsewhere (42-44). 
Table 4. Methodologic quality criteria list (key items of internal validity) of Cochrane Musculoskeletal Review Group

\author{
Patient selection \\ 1. Treatment allocation \\ Was the method of randomization described and adequate? \\ Was the treatment allocation concealed? \\ 2. Were the groups similar at baseline regarding the most important prognostic indicators? \\ Intervention \\ 3. Was the care provider blinded? \\ 4. Was controlled for co-interventions which could explain the results? \\ 5. Was the compliance rate (in each group) unlikely to cause bias? \\ 6. Was the patient blinded? \\ Outcome measurement \\ 7. Was the outcome assessor blinded? \\ 8. Was at least one of the primary outcome measures applied? \\ 9. Was the withdrawal/drop-out rate unlikely to cause bias? \\ Statistics \\ 10. Did the analysis include an intention-to-treat analysis?
}

Adapted from ref 41

Table 5. AHRQ's key domains and elements for systems to rate quality of observational studies

\begin{tabular}{|ll|}
\hline Domain $^{*}$ & Elements $^{*}$ \\
\hline Study Question & - Clearly focused and appropriate question \\
Study Population & - Description of study populations \\
Comparability of Subjects $\dagger$ & - Use of concurrent controls \\
Exposure or Intervention & - Clear definition of exposure \\
& - Measurement method standard, valid and reliable \\
& - Exposure measured equally in all study groups \\
Outcome Measurement & - Primary/secondary outcomes clearly defined \\
Statistical Analysis & - Assessment of confounding factors \\
Results & - Measure of effect for outcomes and appropriate measure \\
& - Co precision \\
Discussion & - Conclusions supported by results with possible biases \\
Funding or Sponsorship & - Type and sources of support for study
\end{tabular}

${ }^{\star}$ Key domains are in italics

\#Elements appearing in italics are those with an empirical basis. Elements appearing in bold are those considered essential to give a system a Yes rating for the domain. For purposes of this systematic review, the bold elements were considered, and to be included studies needed to have at least 5 of the 8 essential elements.

$\dagger$ Domain for which a Yes rating required that a majority of elements be considered.

Adapted from ref 39

\section{Analysis of Evidence}

Qualitative analysis was conducted using five levels of evidence as shown in Table 6.

For therapeutic intraarticular injections the primary outcome measure was pain relief. Other outcome measures utilized were functional improvement, psychological improvement and return to work. For therapeutic interventions with intraarticular injections short-term relief was defined as less than 6 weeks, and longterm relief was defined as 6 weeks or longer. In contrast, for radiofrequency neurotomy, short-term relief was defined as less than 3 months and long-term relief was defined as 3 months or longer.

For diagnostic interventions placebo controlled or comparative, controlled local anesthetic blocks were considered as satisfactory criteria. The criterion of pain relief was considered as appropriate as described by individual authors.

A study was judged to be positive if the authors concluded that it was positive. If the authors concluded a study as negative, and there was a preponderance of evidence showing the positive nature of the study the conclusion was altered for the purposes of analysis of evidence.

RESULTS

Diagnostic Sacroiliac Joint Injections

The database search produced 104 article abstracts for review for diagnostic interventions. Of these, 5 articles were reviewed $(17,18,28,45,46)$. However, 2 were excluded because they were only single injection studies $(17,45)$. The remaining 3 were chosen for the study. All 3 studies were performed under fluoroscopic guidance and employed a comparative, controlled local anesthetic technique. All 3 used a screening lidocaine injection followed by a confirmatory bupivacaine injection of those who had a positive response. Laslett et al (18), however, used steroid after the lidocaine injection. The study was included for review as it was followed by a bupivacaine injection and those patients who had prolonged pain relief following the steroid were excluded from the study. The only randomized study was the one by Manchikanti et al (46). All patients who were selected for the double block had low back pain and all had positive provocative maneuvers to the sacroiliac joint. In none of these studies was a single provocative maneuver diagnostic for sacroiliac joint pain. In these studies, sacroiliac joint pain was seen in $2 \%$ to $18 \%$ of the patients evaluated (18, $28,46)$. Description of included studies along with methodologic quality criteria are illustrated in Table 7.

Maigne et al (28) studied 67 patients who had chronic ( $\geq 50$ days) unilateral low back pain (VAS $\geq 4$ ) with or without radiation to the posterior thigh with associated pain and tenderness over the posterior sacroiliac joint. The block was successful in 54 patients. Double injections were performed with a screening diagnostic lidocaine injection $(2 \mathrm{ml})$ performed first. Relief of $\geq 75 \%$ relief was considered a positive result. Nineteen of 54 patients had $\geq 75 \%$ relief from the screening block 
Table 6. Designation of levels of evidence

\begin{tabular}{|ll|}
\hline Level I & $\begin{array}{l}\text { Conclusive: Research-based evidence with multiple relevant and high-quality scientific studies or consistent reviews of meta- } \\
\text { analyses }\end{array}$ \\
Level II & $\begin{array}{l}\text { Strong: Research-based evidence from at least one properly designed randomized, controlled trial; or research-based evidence } \\
\text { from multiple properly designed studies of smaller size; or multiple low quality trials. }\end{array}$ \\
Level III & $\begin{array}{l}\text { Moderate: a) Evidence obtained from well-designed pseudorandomized controlled trials (alternate allocation or some other } \\
\text { method); b) evidence obtained from comparative studies with concurrent controls and allocation not randomized (cohort } \\
\text { studies, case-controlled studies, or interrupted time series with a control group); c) evidence obtained from comparative } \\
\text { studies with historical control, two or more single-arm studies, or interrupted time series without a parallel control group. }\end{array}$ \\
Level IV $\quad \begin{array}{l}\text { Limited: Evidence from well-designed nonexperimental studies from more than one center or research group; or conflicting } \\
\text { evidence with inconsistent findings in multiple trials }\end{array}$ \\
Level V $\quad \begin{array}{l}\text { Indeterminate: Opinions of respected authorities, based on clinical evidence, descriptive studies, or reports of expert } \\
\text { committees. }\end{array}$
\end{tabular}

Adapted from ref 43, 44

and 10 of 19 participants had $\geq 75 \%$ improvement from the confirmatory block. Of the 54,10 or $18.5 \%$ were considered to have sacroiliac joint pain. As only patients with a high likelihood of sacroiliac joint pain were included in the study, no determination of the prevalence of sacroiliac joint pain can be made.
Manchikanti et al (46) evaluated 120 patients that presented to the pain clinic with low back pain for $\geq 6$ months. All of the participants initially had facet blocks and were negative for facet joint pain. Patients without facet joint pain, but with suspected sacroiliac joint involvement (pain in the sacral region, sacroiliac joint tenderness and positive provocative maneuvers) had a sacroiliac joint injection. They had screening sacroiliac joint injections with $2 \%$ lidocaine followed in 3 to 4 weeks by confirmatory bupivacaine blocks. Twenty of 120 patients had sacroiliac joint injections and 6 of 20 patients had a positive response to the screening

Table 7. Characteristics of reported prospective diagnostic studies

\begin{tabular}{|c|c|c|c|c|}
\hline Study & Participants & Objective(s) & Intervention(s) & Result(s) \\
\hline $\begin{array}{l}\text { Maigne et al (28) } \\
\text { AHRQ Score } \\
3 / 5 \\
\text { QUADAS Score } \\
\text { 10/14 }\end{array}$ & $\begin{array}{l}77 \text { patients aged } 18-75 \\
\text { attending a public hospital } \\
\text { with chronic unilateral LBP } \\
\text { with or without radiation to } \\
\text { the posterior thigh for }>50 \\
\text { days (median } 4.2 \text { months). } \\
\text { Patients had failed epidural } \\
\text { or lumbar facet injections. }\end{array}$ & $\begin{array}{l}\text { Determine the } \\
\text { prevalence of } \\
\text { sacroiliac joint pain in } \\
\text { a selected population } \\
\text { of patients with } \\
\text { low back pain and } \\
\text { assess certain pain } \\
\text { provocation tests. }\end{array}$ & $\begin{array}{l}\text { Successful blockade of } \\
\text { the sacroiliac joint in } \\
54 \text { patients. A screen- } \\
\text { ing block was done } \\
\text { with } 2 \% \text { lidocaine and } \\
\text { a confirmatory block } \\
\text { was performed with } \\
\text { bupivacaine } 0.5 \% \geq \\
75 \% \text { relief was consid- } \\
\text { ered a positive block. }\end{array}$ & $\begin{array}{l}19 / 54 \text { patients had }>75 \% \\
\text { relief with lidocaine. } 10 / 19 \\
\text { patients had relief with } \\
\text { confirmatory bupivacaine and } \\
\text { were considered to have SIJ } \\
\text { pain. There was no statistically } \\
\text { significant association between } \\
\text { response to blocks and any } \\
\text { single clinical parameter. No } \\
\text { pain provocation test predicted } \\
\text { SIJ pain. }\end{array}$ \\
\hline $\begin{array}{l}\text { Manchikanti et } \\
\text { al (46) } \\
\text { AHRQ Score } \\
4 / 5 \\
\text { QUADAS Score } \\
11 / 14\end{array}$ & $\begin{array}{l}120 \text { patients (age 18-90) } \\
\text { presenting to the clinic with } \\
>6 \text { months of low back pain } \\
\text { and no structural basis for } \\
\text { the pain by radiographic } \\
\text { imaging. Patients who } \\
\text { failed facet blocks, had SIJ } \\
\text { tenderness, and positive } \\
\text { provocative maneuvers had } \\
\text { an SIJ injection. }\end{array}$ & $\begin{array}{l}\text { Determine the } \\
\text { frequency of various } \\
\text { structures responsible } \\
\text { for low back pain. }\end{array}$ & $\begin{array}{l}\text { All patients had facet } \\
\text { blocks. Nonresponders } \\
\text { who fit criteria had } \\
\text { double injection SIJ } \\
\text { blocks. The screening } \\
\text { block was done with } \\
2 \% \text { lidocaine and the } \\
\text { confirmatory block was } \\
\text { performed using } 0.5 \% \\
\text { bupivacaine. }\end{array}$ & $\begin{array}{l}20 \text { patients had clinical diagnosis } \\
\text { of SIJ pain. } 6 / 20 \text { had } \geq 75 \% \\
\text { relief from the lidocaine blocks. } \\
2 / 6 \text { had } \geq 75 \% \text { relief from } \\
\text { the bupivacaine blocks. The } \\
\text { incidence of SIJ pain was } 2 \% \text { of } \\
\text { the overall sample and } 10 \% \text { of } \\
\text { those suspected to have SIJ pain. } \\
\text { The false positive rate was } 22 \% \text {. }\end{array}$ \\
\hline $\begin{array}{l}\text { Laslett et al (18) } \\
\text { AHRQ Score } \\
5 / 5 \\
\text { QUADAS Score } \\
12 / 14\end{array}$ & $\begin{array}{l}62 \text { patients with buttock } \\
\text { pain with or w/o LE } \\
\text { involvement referred for } \\
\text { diagnostic injections. } \\
\text { Patients failed prior } \\
\text { interventions and had prior } \\
\text { imaging studies. }\end{array}$ & $\begin{array}{l}\text { Comparison of SIJ } \\
\text { provocative tests and } \\
\text { reasoning process } \\
\text { using McKenzie } \\
\text { evaluation with SIJ } \\
\text { double injections. }\end{array}$ & $\begin{array}{l}48 \text { patients had SIJ } \\
\text { diagnostic injection } \\
\text { with Lidocaine. After } \\
\text { symptom reproduction } \\
\text { steroid was added. } 16 \\
\text { patients had pain relief. } \\
5 \text { remained pain free } \\
\text { and } 11 \text { had confirma- } \\
\text { tory blocks and all were } \\
\text { positive. }\end{array}$ & $\begin{array}{l}\text { There was a } 91 \% \text { sensitivity and } \\
78 \% \text { specificity when double SI } \\
\text { Joint injection was compared } \\
\text { to } \geq 3 \text { SI Joint pain provocation } \\
\text { tests and clinical reasoning. }\end{array}$ \\
\hline
\end{tabular}


block. Of those 6 patients, 2 had a positive response to the confirmatory bupivacaine block resulting in a $2 \%$ prevalence of sacroiliac joint pain. A definite or positive response was defined as $\geq 80 \%$ relief of pain.

Laslett et al (18) sought to validate a specific clinical examination and reasoning to diagnose sacroiliac joint pain by confirming the diagnosis by diagnostic injections. They evaluated 62 patients who presented to the clinic with buttock pain with or without lower extremity pain for diagnostic injections. Patients with pain above L5 and those with midline or symmetric pain were excluded. The patients had a clinical examination by a physical therapist who was blinded to the imaging studies. A radiologist who was blinded to the results of the clinical examination performed double sacroiliac joint injections. The screening sacroiliac joint injection performed with lidocaine $(<1.5 \mathrm{~mL})$ was considered a positive injection if the injection provoked familiar pain and resulted in $\geq 80 \%$ pain relief. Once the injection recreated the patient's familiar pain, steroid was then injected into the joint. Forty-eight patients had the screening lidocaine injection. Sixteen of $48 \mathrm{had} \geq 80 \%$ pain relief. Of those, 5 remained pain free and were then excluded. Eleven patients went on to have the confirmatory bupivacaine injections, all of them were positive. Of note, 10 of 11 sacroiliac joint injections met the clinical examination criteria for having sacroiliac joint pain and the diagnostic accuracy of the clinical examination and clinical reasoning process was found to be superior to the sacroiliac joint pain provocation tests alone. The steroid added to the screening aspect of this study makes it more difficult to interpret. In addition, the patients studied were not consecutive; consequently, this study was subject to verification bias. Thus, 10 of $62(16 \%)$ patients studied had sacroiliac joint pain as defined by pain relief following a double local anesthetic injection.

\section{Accuracy}

Sacroiliac joint blocks have been shown to have face validity. Low volumes of local anesthetic selectively injected into the target joint after dye verification of the needle position may anesthetize the joint. Appropriate precautions need to be observed to ensure there is no extravasation to adjacent structures (62).
Sacroiliac joint blocks also have been shown to have construct validity. However, to have construct validity, sacroiliac joint blocks must be controlled. Single diagnostic blocks carry a false-positive rate of $20 \%$ (28). Patients are liable to report relief of pain after diagnostic block for reasons other than the pharmacological action of drug administration (47). Consequently, it is imperative to know in every individual case whether the response is a true positive. The validity of controlled comparative local anesthetic blocks for facet joint diagnostic blocks was confirmed with placebo controlled diagnostic blocks $(47,48)$.

False positive rate of diagnostic sacroiliac joint injection was evaluated in two groups of patients, with a false positive rate of $20 \%$ (28) and $22 \%$ (46). It is also possible to have extravasation of the local anesthetic if care is not taken to avoid spill over into adjacent structures (62).

\section{Prevalence}

This review led to inclusion of two studies $(28,46)$ utilizing controlled local anesthetic blocks.

Schwarzer et al (17) utilized a single local anesthetic block. Thus, the value of this evaluation is unknown. Pang et al (45) also utilized single block with a prevalence report of $10 \%$ of chronic low back pain patients. Laslett (18) used a double block paradigm but confused the data by following the lidocaine injection with steroid, which made the blocks more therapeutic in nature. Indeed 5 patients remained pain free throughout the study and had to be eliminated. Maigne et al (28), even though utilizing a double block paradigm that validated the diagnostic ability of the test with false-positive rates, failed to provide the prevalence rate in chronic spinal pain populations, as it was performed in a select group of patients with suspicion of sacroiliac joint pain. Finally, Manchikanti et al (46) showed a low prevalence of sacroiliac joint pain with a double block paradigm. The study was performed in patients suffering with low back pain and negative for other sources of pain.

Even though short-term relief from sacroiliac joint injection is considered as a gold standard for the diagnosis of sacroiliac joint pain, there was no blinded comparison of the test or reference standard in evaluation of these investigations .

\section{Level of Evidence}

Based on the present evaluation of three controlled trials $(18,28,46)$, the evidence for sacroiliac joint diagnostic blocks in diagnosing pain of sacroiliac joint originwas moderate.

\section{Therapeutic Sacroiliac Joint Interventions}

Sacroiliac joint pain may be managed by intraarticular injections, or neurolysis of sacroiliac joint innervation.

\section{Intraarticular Blocks}

Our search criteria yielded 28 reports describing the effectiveness of these interventions. From these, 6 relevant evaluations were selected for review and evidence synthesis (49-54). Of these, two studies were randomized $(49,50), 3$ were prospective evaluations (51-53), and one was a retrospective evaluation (54).

\section{Methodological Quality}

Of the two randomized trials selected for review, one study (49) was excluded due to lack of long-term follow-up (1 month), and injection was periarticular. Consequently only one randomized trial (50) was available for review. Among the 3 prospective evaluations (51-53), one evaluation (51) was excluded as it failed to meet inclusion criteria with evaluation of short-term relief. The second evaluation was in the German language (52). Consequently, only one study (53) was included in the evidence synthesis. However, both prospective studies $(50,53)$ evaluated spondyloarthropathy. Since there were no other studies [except one retrospective study (54)] evaluating non-inflammatory sacroiliac joint pain, it was decided to include these two studies. Further, the only study evaluating non-inflammatory sacroiliac joint pain (54) was included, even though they studied some patients with pain of 6 weeks duration.

One retrospective evaluation (54) was included. These studies are listed in Table 8.

\section{Study Characteristics}

The characteristics of reported studies are listed in Table 8.

Maugars et al (50) performed a double-blind study in 10 patients; 13 articulations, suffering with painful sacroiliitis. Six sacroiliac joints were injected with steroid and 7 were placebo injections. At 1 month, 5/6 sacroiliac joints were inject- 
Table 8. Study characteristics of included reports of therapeutic intraarticular sacroiliac joint injections

\begin{tabular}{|c|c|c|c|c|c|}
\hline Study & Participants & Objective(s) & Intervention(s) & $\begin{array}{r}\mathbf{R e} \\
\text { Short-ter } \\
\text { Long-ter }\end{array}$ & $\begin{array}{l}\text { lts } \\
\text { relief }<6 \text { weeks } \\
\text { relief } \geq 6 \text { weeks }\end{array}$ \\
\hline $\begin{array}{l}\text { Maugars et al (50) } \\
\text { Randomized, } \\
\text { controlled trial } \\
\text { AHRQ Score } \\
6 / 10 \\
\text { Cochrane Score } \\
6 / 10\end{array}$ & $\begin{array}{l}10 \text { patients } / 13 \text { articu- } \\
\text { lations with painful } \\
\text { sacroiliitis. }\end{array}$ & $\begin{array}{l}\text { To assess the effec- } \\
\text { tiveness of sacroiliac } \\
\text { corticosteroid injec- } \\
\text { tions in spondyloar- } \\
\text { thropathy. }\end{array}$ & $\begin{array}{l}\text { Sacroiliac joint } \\
\text { injection with } \\
\text { steroids or pla- } \\
\text { cebo. }\end{array}$ & $\begin{array}{l}86 \% \text { of patients had a good result } \\
\text { at } 1 \text { month, } 62 \% \text { at } 3 \text { months, and } \\
58 \% \text { at } 6 \text { months. }\end{array}$ & $\begin{array}{l}\text { Positive } \\
\text { short-term } \\
\text { and long- } \\
\text { term }\end{array}$ \\
\hline $\begin{array}{l}\text { Hanly et al (53) } \\
\text { Prospective } \\
\text { evaluation } \\
\text { AHRQ Score } \\
5 / 8\end{array}$ & $\begin{array}{l}19 \text { patients with } \\
\text { symptoms of LBP } \\
\text { were studied. } 13 \text { had } \\
\text { radiographic evidence } \\
\text { of sacroiliitis. The } \\
\text { remaining } 6 \text { patients } \\
\text { had normal imaging } \\
\text { studies and thus were } \\
\text { considered to have } \\
\text { mechanical low back } \\
\text { pain. }\end{array}$ & $\begin{array}{l}\text { To evaluate changes } \\
\text { in articular symp- } \\
\text { toms, spinal mobility, } \\
\text { and global function } \\
\text { over } 6 \text { months after } \\
\text { intraarticular injec- } \\
\text { tions of long acting } \\
\text { corticosteroid into } \\
\text { the sacroiliac (SI) } \\
\text { joints of patients } \\
\text { with inflammatory } \\
\text { low back pain. }\end{array}$ & $\begin{array}{l}\text { All patients } \\
\text { received bilat- } \\
\text { eral SI joint } \\
\text { injections of } \\
\text { triamcinolone } \\
\text { hexacetonide } \\
\text { (40 mg/joint) } \\
\text { under comput- } \\
\text { er tomographic } \\
\text { guidance. }\end{array}$ & $\begin{array}{l}\text { Both groups of patients showed } \\
\text { a transient improvement in stiff- } \\
\text { ness and pain, spinal mobility, } \\
\text { and general health status that was } \\
\text { most pronounced at } 1-3 \text { months } \\
\text { after intraarticular therapy. This } \\
\text { did not reach statistical signifi- } \\
\text { cance ( } p>0.05 \text { ) and by } 6 \text { months } \\
\text { followup all outcome variables } \\
\text { had reverted to pretherapy levels } \\
\text { in both groups. }\end{array}$ & $\begin{array}{l}\text { Positive - } \\
\text { short term } \\
\text { Negative - } \\
\text { long term }\end{array}$ \\
\hline $\begin{array}{l}\text { Slipman et al (54) } \\
\text { Retrospective } \\
\text { evaluation } \\
\text { AHRQ Score } \\
6 / 8\end{array}$ & $\begin{array}{l}31 \text { patients were in- } \\
\text { cluded; each patient } \\
\text { met specific physical } \\
\text { examination criteria } \\
\text { and failed to improve } \\
\text { clinically after at } \\
\text { least } 4 \text { wk of physical } \\
\text { therapy. Each patient } \\
\text { demonstrated a posi- } \\
\text { tive response to a fluo- } \\
\text { roscopically guided } \\
\text { diagnostic sacroiliac } \\
\text { joint injection. }\end{array}$ & $\begin{array}{l}\text { To investigate the } \\
\text { outcomes resulting } \\
\text { from the use of fluo- } \\
\text { roscopically guided } \\
\text { therapeutic sacroiliac } \\
\text { joint injections in pa- } \\
\text { tients with sacroiliac } \\
\text { joint syndrome. }\end{array}$ & $\begin{array}{l}\text { Therapeutic } \\
\text { sacroiliac joint } \\
\text { injections were } \\
\text { administered } \\
\text { in conjunction } \\
\text { with physical } \\
\text { therapy. }\end{array}$ & $\begin{array}{l}\text { Patients'symptom duration before } \\
\text { diagnostic injection averaged } 20.6 \\
\text { mo. An average of } 2.1 \text { therapeutic } \\
\text { injections was administered. } \\
\text { Follow-up data collection was } \\
\text { obtained at an average of } 94.4 \\
\text { wk. A significant reduction ( } \\
=0.0014) \text { in Oswestry disability } \\
\text { score was observed at the time of } \\
\text { follow-up. VAS pain scores were } \\
\text { reduced }(\mathrm{P}<0.0001) \text { at the time } \\
\text { of discharge and at follow-up. } \\
\text { Work status was also significantly } \\
\text { improved at the time of discharge } \\
(\mathrm{P}=0.0313) \text { and at follow-up }(\mathrm{P} \\
=0.0010) \text {. A trend }(\mathrm{P}=0.0645) \\
\text { toward less drug usage was } \\
\text { observed. }\end{array}$ & $\begin{array}{l}\text { Positive } \\
\text { short-term } \\
\text { and long- } \\
\text { term }\end{array}$ \\
\hline
\end{tabular}

ed with corticosteroid, (in comparison to $0 / 7$ of the placebo group), described a relief of $\geq 70 \%$, $(\mathrm{P}<0.05)$. Six out of the seven sacroiliac joints of the placebo group and 2 patients from the corticosteroid group who either failed the first injection or whose pain returned, were reinjected with corticosteroid. At 1 month, 12/ $14(85.7 \%)$ had good results and patients were still significantly better at 3 months (62\%) and 6 months (58\%).

Hanly et al (53) studied changes in articular symptoms, spinal mobility, and global function over 6 months after intraarticular injections of long acting corticosteroid into the sacroiliac joints of 19 patients with low back pain. Thirteen (68\%) had radiographic evidence of sacroiliitis and were considered to have in- flammatory low back pain, 6 patients (32\%) had normal imaging studies and thus were considered to have mechanical low back pain. All patients received bilateral SI joint injections of triamcinolone hexacetonide (40 mg/joint) under computer tomographic guidance. Outcome variables included the duration of low back morning stiffness back pain (by visual analog scale, McGill Pain Questionnaire), spinal mobility (chest expansion, Schober test, $10 \mathrm{~cm}$ segments test, fingerfibula distance), and self-report health status (SF-36). The resulting improvement in stiffness and pain as well as improved spinal mobility were transient and were most pronounced at 1-3 months after the injections. This did not reach statistical significance $(\mathrm{p} \geq 0.05)$ and by 6 months follow-up all outcome variables had reverted to pretherapy levels in both groups. Based on these preliminary observations, SI corticosteroid injections were considered to be ineffective in the management of patients with inflammatory spondyloarthropathy.

Slipman et al (54), in a retrospective evaluation with independent clinic review, evaluated the use of fluoroscopically guided therapeutic sacroiliac joint injections in patients with sacroiliac joint syndrome. The symptom duration of this patient population was as early as 1.5 months prior to inclusion in the study with an average symptom duration of 20.6 months. They reported a significant reduction $(\mathrm{P}=0.0014)$ in Oswestry disability scores at the time of follow- 
up. Visual Analog Scale pain scores were reduced $(\mathrm{P}<0.0001)$ at the time of discharge and at follow-up. Work status was also significantly improved at the time of discharge $(\mathrm{P}=0.0313)$ and at follow-up $(\mathrm{P}=0.0010)$. A trend $(\mathrm{P}=0.0645)$ toward less drug usage was observed. They concluded that fluoroscopically guided therapeutic sacroiliac joint injections are a clinically effective intervention in the treatment of patients with sacroiliac joint syndrome.

\section{Evidence Synthesis}

The present systematic review included one randomized trial (50), one prospective trial (53), and one retrospective evaluation (54). The randomized trial (50) showed positive results both for short-term and long-term. The prospective trial (53) showed positive short-term and negative long-term results in spondyloarthropathy. The retrospective evaluation showed positive results. Thus it was concluded that evidence for intraarticular sacroiliac joint injections was moderate for short-term relief and limited for longterm relief.

\section{Radiofrequency Neurotomy}

Percutaneous radiofrequency neurotomy of sacroiliac joint innervation has been described to provide long-term relief. Our literature search yielded 46 reports. There were 4 relevant reports available for review (55-58). Of these, one (55) was prospective, and 3 were retrospective (56-58).

\section{Methodological Quality}

The one and only available prospective evaluation (55) was of 3-month fol- low-up. Consequently, it failed to meet inclusion criteria. All of the three retrospective reports (56-58) met inclusion criteria (Table 9).

\section{Study Characteristics}

Ferrante et al (56), in a retrospective report, published the results of a consecutive series of 50 sacroiliac joint radiofrequency denervations performed in 33 patients with sacroiliac joint syndrome. All patients underwent diagnostic sacroiliac joint injections with local anesthetic before denervation. Outcome parameters included changes in visual analog pain scores, pain diagrams, physician examination including tenderness overlying the joint, SI joint pain provocation test, and range of motion of the lumbar spine, and opioid use pre- and post denervation. The defined criteria for successful radio-

Table 9. Description of studies evaluating radiofrequency neurotomy of sacroiliac joint

\begin{tabular}{|c|c|c|c|c|c|}
\hline Study & Participants & Objective(s) & Intervention(s) & \multicolumn{2}{|c|}{$\begin{aligned} & \text { Result }(\mathbf{s}) \\
\text { Short-term relief } & <3 \text { months } \\
\text { Long-term relief } & \geq 3 \text { months }\end{aligned}$} \\
\hline $\begin{array}{l}\text { Ferrante et al (56) } \\
\text { AHRQ Score } \\
4 / 8\end{array}$ & $\begin{array}{l}33 \text { patients } \\
\text { with sacroiliac } \\
\text { syndrome. }\end{array}$ & $\begin{array}{l}\text { Radiofrequency (RF) } \\
\text { denervation of the } \\
\text { sacroiliac (SI) joint } \\
\text { has been advocated } \\
\text { for the treatment of } \\
\text { sacroiliac syndrome, } \\
\text { yet no clinical stud- } \\
\text { ies or case series } \\
\text { support its use. }\end{array}$ & $\begin{array}{l}\text { All patients under- } \\
\text { went diagnostic SI } \\
\text { joint injections with } \\
\text { local anesthetic be- } \\
\text { fore denervation. }\end{array}$ & $\begin{array}{l}\text { The criteria for successful RF denerva- } \\
\text { tion were at least a } 50 \% \text { decrease in VAS } \\
\text { for a period of at least } 6 \text { months; } 36.4 \% \\
\text { of patients }(12 \text { of } 33) \text { met these criteria. } \\
\text { Failure of denervation correlated with } \\
\text { the presence of disability determina- } \\
\text { tion and pain on lateral flexion to the } \\
\text { affected side. The average duration of } \\
\text { pain relief was } 12.0+/-1.2 \text { months in } \\
\text { responders versus } 0.9+/-0.2 \text { months in } \\
\text { nonresponders }(\mathrm{P}<\text { or }=0.0001) \text {. }\end{array}$ & $\begin{array}{l}\text { Negative } \\
\text { short-term } \\
\text { and long- } \\
\text { term }\end{array}$ \\
\hline $\begin{array}{l}\text { Yin et al (57) } \\
\text { AHRQ Score } \\
4 / 8\end{array}$ & $\begin{array}{l}14 \text { patients } \\
\text { met inclusion } \\
\text { criteria for } \\
\text { this retrospec- } \\
\text { tive study. }\end{array}$ & $\begin{array}{l}\text { To examine the } \\
\text { effectiveness of } \\
\text { sensory stimulation- } \\
\text { guided radiofre- } \\
\text { quency neurotomy } \\
\text { for the treatment of } \\
\text { recalcitrant sacro- } \\
\text { iliac joint pain. }\end{array}$ & $\begin{array}{l}\text { Sensory stimula- } \\
\text { tion-guided sacral } \\
\text { lateral branch ra- } \\
\text { diofrequency neu- } \\
\text { rotomy after dual } \\
\text { analgesic sacroiliac } \\
\text { joint deep interos- } \\
\text { seous ligament } \\
\text { analgesic testing. }\end{array}$ & $\begin{array}{l}\text { Sixty-four percent of patients experi- } \\
\text { enced a successful outcome, with } 36 \% \\
\text { experiencing complete relief. Fourteen } \\
\text { percent of patients did not achieve any } \\
\text { improvement. }\end{array}$ & $\begin{array}{l}\text { Positive } \\
\text { short-term } \\
\text { and long- } \\
\text { term }\end{array}$ \\
\hline $\begin{array}{l}\text { Cohen and Abdi } \\
\text { (58) } \\
\text { AHRQ Score } \\
4 / 8\end{array}$ & $\begin{array}{l}9 \text { patients who } \\
\text { experienced } \\
>50 \% \text { pain re- } \\
\text { lief underwent } \\
\text { RF lesioning } \\
\text { of the nerves. }\end{array}$ & $\begin{array}{l}\text { The purpose of this } \\
\text { study was to deter- } \\
\text { mine the efficacy } \\
\text { of reducing SI joint } \\
\text { pain by percutane- } \\
\text { ous RF lesioning of } \\
\text { the nerves innervat- } \\
\text { ing the SI joint }\end{array}$ & $\begin{array}{l}\text { Nerve blocks of the } \\
\text { L4-5 primary dor- } \\
\text { sal rami and S1-3 } \\
\text { lateral branches } \\
\text { innervating the af- } \\
\text { fected joint. } \\
\text { RF lesioning of the } \\
\text { nerves. }\end{array}$ & $\begin{array}{l}13 \text { of } 18 \text { patients who underwent } \mathrm{L} 4-5 \\
\text { dorsal rami and S1-3 lateral branch } \\
\text { blocks (LBB) obtained significant } \\
\text { pain relief, with } 2 \text { patients reporting } \\
\text { prolonged benefit. At their next visit, } \\
9 \text { patients who experienced }>50 \% \text { pain } \\
\text { relief underwent RF lesioning of the } \\
\text { nerves. Eight of } 9 \text { patients ( } 89 \% \text { ) ob- } \\
\text { tained }>/=50 \% \text { pain relief from this } \\
\text { procedure that persisted at their 9- } \\
\text { month follow-up. }\end{array}$ & $\begin{array}{l}\text { Positive } \\
\text { short-term } \\
\text { and long- } \\
\text { term }\end{array}$ \\
\hline
\end{tabular}


frequency denervation was at least a $50 \%$ decrease in VAS for a period of at least 6 months. The results showed that 12 of 33 patients or $36 \%$ of the patients met the criteria for successful denervation. The average duration of pain relief was $12.0 \pm$ 1.2 months in responders versus $0.9 \pm 0.2$ months in non-responders $(\mathrm{P} \leq .0001)$. They also noted that a positive response was associated with an atraumatic inciting event. They concluded that radiofrequency denervation of the sacroiliac joint can significantly reduce pain in selected patients with sacroiliac joint syndrome for a protracted time. With a 6-month response of only $36 \%$ of the patients this study is judged as negative by the authors of this review.

Yin et al (57), in a retrospective audit and examination of anatomic findings as well as the effectiveness of sensory stimulation-guided radiofrequency neurotomy for the treatment of recalcitrant sacroiliac joint pain, studied 14 patients. They defined success as greater than $60 \%$ consistent subjective relief and greater than a $50 \%$ consistent decrease in pain score maintained for at least 6 months after the procedure. They reported that $64 \%$ of the patients experienced a successful outcome with $36 \%$ experiencing complete relief. The authors concluded that a sensory stimulation-guided approach toward the identification and subsequent radiofrequency thermocoagulation of symptomatic sacral lateral branch nerves appears to offer significant therapeutic advantages over existing therapies for the treatment of chronic sacroiliac joint complex pain. Even though this study included only 14 patients that met the inclusion criteria, the authors of the study as well as authors of this systematic review considered this study positive.

Cohen and Abdi (58) performed radiofrequency lesioning on 9 patients who experienced greater than $50 \%$ pain relief following nerve blocks of the L4-5 primary dorsal rami and S1-3 lateral branches innervating the affected joint. Eight of 9 patients $(89 \%)$ obtained $50 \%$ or greater pain relief from this procedure that persisted at their 9-month follow-up. The authors concluded that in patients with sacroiliac joint pain who respond to L4L5 dorsal rami and S1-3 lateral branch blocks, radiofrequency denervation of these nerves appears to be an effective treatment. The authors of this study and the authors of this systematic review con- sidered this retrospective evaluation as positive.

\section{Evidence Synthesis}

Based on the available literature, which consisted of 3 retrospective evaluations with small numbers of patients, the evidence for radiofrequency neurotomy in managing chronic sacroiliac joint pain was limited.

\section{Safety and Complications}

No complications have been reported in any of the studies included in this review. However, potential complications include infection, hematoma formation, neural damage, trauma to the sciatic nerve, gas and vascular particulate embolism, leakage of the drug from the joint, and other complications related to drug administration. Without fluoroscopy, successful joint injection is documented in only $12 \%$ to $22 \%$ of the cases (59). Rosenberg, et al (59) also showed that there was epidural spread in $24 \%$ of the patients and contrast was noted in the sacral foramen in $44 \%$ of the patients. Others (60) also have shown low rate of accurate placement of the needle into the joint without fluoroscopy.

\section{Discussion}

This systematic evaluation of diagnostic and therapeutic interventions of the sacroiliac joint showed moderate evidence of accuracy of diagnostic sacroiliac joint blocks with a prevalence of $10 \%$ to $19 \%$ and a false positive rate of 20 to $22 \%$. This evaluation also showed limited evidence for the therapeutic effectiveness of intraarticular injections and radiofrequency neurotomy in managing sacroiliac joint pain.

The results of this systematic evaluation are similar to previous reports assessing the value and validity of sacroiliac joint injections (43). However, there were no reports of systematic reviews of sacroiliac joint injections. As expected, the literature on diagnostic and therapeutic interventions of the sacroiliac joint is scarce. However the literature on diagnostic sacroiliac joint injections is superior to the literature on therapeutic interventions. Due to the lack of significant literature, the level of evidence was low, even with inclusion of studies of spondyloarthropathies. The relationship of sacroiliac joint pain and its management with and without inflammatory arthropathy is not known. Consequently, it is imperative that previous studies are replicated and high quality evidence produced.

There is no doubt that sacroiliac joints are innervated and are capable of producing low back and referred pain in the lower extremity (8-17). Diagnostic criteria for sacroiliac joint syndrome as defined by the International Association for the Study of Pain (IASP) (21) included pain in the region of the sacroiliac joint with possible radiation to the groin, medial buttocks and posterior thigh; reproduction of pain by physical examination techniques that stress the joint; elimination of pain with intraarticular injection of local anesthetic; and a morphologically normal joint with demonstrable pathognomic radiographic abnormalities. Of this criterion, pain referral patterns have been well described (14-17). However, with regards to the second criterion, the reproduction of pain by physical examination techniques that stress the joint, positive correlations have been reported by some $(18,24,25)$, while others have refuted these criterion (17, 19, 20, 26-28). The third criterion, described by IASP as elimination of pain with intraarticular injection of local anesthetic, was demonstrated in multiple evaluations $(17,18$, $28,45,46)$. Finally, the last criterion describing a morphologically normal joint without demonstrable radiographic abnormalities or lack of correlation of radiographic abnormalities also has been illustrated $(3-5,22,23,29-37,40)$. Historically, in the early 1900's, Goldthwait first proposed the sacroiliac joint (2) and facet joints (61) to be potential pain generators. After 100 years, these early propositions have been proven.

The strength of our systematic review is based on its compliance with strict criteria for evaluation of diagnostic tests as established by AHRQ (39), and QUADAS (40). The criteria for therapeutic management also included AHRQ criteria for observational studies. We also applied Cochrane review criteria for one randomized trial. The inability of a physician to provide appropriate and accurate diagnosis for a patient with chronic spinal pain including that of sacroiliac joint pain continues to be frustrating. Even though, some of the recent literature suggests that sacroiliac joint pain can be diagnosed based on provocative maneuvers $(18,25,26)$, the authors of this systematic review find this to be far from a reali- 
ty. Further studies are required to prove this assertion.

\section{ConCLUSION}

This systematic review showed moderate evidence for the accuracy of diagnostic sacroiliac joint injections in the diagnosis of sacroiliac joint pain. This systematic review also showed moderate evidence for therapeutic intraarticular sacroiliac joint injections and limited evidence for radiofrequency neurotomy in managing chronic sacroiliac joint pain.

\section{Author AfFiliation}

Ann Marie McKenzie-Brown, MD Assistant Professor of Anesthesiology Division Director, Division of Pain Medicine Emory Department of Anesthesiology Emory Center for Pain Medicine 550 Peachtree Street, NE Atlanta GA 30308 anne_marie_mckenziebrown@emory.org

Rinoo V. Shah, MD

Assistant Professor

Pain Fellowship Director

Interventional Pain Institute

Texas Tech University Health Sciences Center

4430 South Loop 289

Lubbock, TX 79414

rinoo_shah@yahoo.com

\section{Nalini Sehgal, MD}

Assistant Professor of Rehabilitation

Medicine

Medical Director of Interventional Pain

Program

University of Wisconsin Hospital \&

Clinics

E3/268 Clinical Science Center

600 Highland Avenue

Madison, WI 53792-3228

n.sehgal@hosp.wisc.edu

\section{Clifford R. Everett, MD}

Assistant Professor,

Department of Orthopaedics

and Physical Medicine and

Rehabilitation

University of Rochester Medical Center

601 Elmwood Avenue, Box 65

Rochester, NY 14642

clifford_everett@URMC.Rochester.edu

\section{References}

1. Mixter WJ, Barr JS. Rupture of the intervertebral disc with involvement of the spinal cord. N Engl J Med 1934; 211:210-214.

2. Goldthwait JE, Osgood RB. A consideration of the pelvic articulations from an anatomical pathological and clinical standpoint. Boston Med Surg / 1905; 152: 593-601.

3. Hansen HC, Helm S. Sacroiliac joint pain and dysfunction. Pain Physician 2003; 6: 179-189.

4. Slipman, CW, Whyte WS, Chow DW, Chou L, Lenrow D, Ellen M. Sacroiliac joint syndrome. Pain Physician 2001; 4:143-152.

5. Slipman CW, Huston CW. Diagnostic sacroiliac joint injections. In Manchikanti L, Slipman CW, Fellows B (eds). Interventional Pain Management: Low Back Pain - Diagnosis and Treatment. ASIPP Publishing, Paducah, KY 2002; 269-274.

6. Pool-Goudzwaard A, Hoek van Dijke G, Mulder P, Spoor C, Snijders C, Stoeckart $R$. The iliolumbar ligament: its influence of stability of the sacroiliac joint. Clin Biomech 2003; 18:99-105.

7. Chou LH, Slipman CW, Bhagia SM, Tsaur L, Bhat AL, Isaac Z, Gilchrist R, El Abd OH, Lenrow DA. Inciting events initiating injection-proven sacroiliac joint syndrome. Pain Med 2004; 5:26-32.

8. Murata Y, Takahashi K, Yamagata M, Takahashi Y, Shimada Y, Moriya H. Origin and pathway of sensory nerve fibers to the ventral and dorsal sides of the sacroiliac joint in rats. J Orthop Res 2001; 19:379383.

9. Fortin JD, Kissling RO, O'Connor BL, Vilensky JA. Sacroiliac joint innervation and pain. Am J Orthop 1999; 28:687-690.

10. Grob KR, Neuhuber WL, Kissling RO. Innervation of the sacroiliac joint of the human. Z Rheumatol 1995; 54:117-122.

11. Ikeda R. Innervation of the sacroiliac joint. Macroscopical and histological studies. Nippon Ika Daigaku Zasshi 1991; 58:587596.

12. Vilensky JA, O'Connor BL, Fortin JD, Merkel GJ, Jimenez AM, Scofield BA, Kleiner JB. Histologic analysis of neural elements in the human sacroiliac joint. Spine 2002; 27:1202-1207.

13. Sakamoto N, Yamashita T, Takebayashi T, Sekine M, Ishii S. An electrophysiologic study of mechanoreceptors in the sacroiliac joint and adjacent tissues. Spine 2001; 26:E468-E471.

14. Fortin JD, Dwyer AP, West S, Pier J. Sacroiliac joint: Pain referral maps upon applying a new injection/arthrography technique. Part I: Asymptomatic volunteers. Spine 1994; 19:1475-1482.

15. Fortin JD, Aprill CN, Ponthieux B, Pier J. Sacroiliac joints: Pain referral maps upon applying a new injection/arthrography technique. Part II: Clinical evaluation. Spine 1994; 19:1483-1489.

16. Slipman CW, Jackson HB, Lipetz JS, Chan
KT, Lenrow D, Vresilovic EJ. Sacroiliac joint pain referral zones. Arch Phys Med Rehabil 2000; 81:334-338.

17. Schwarzer AC, Aprill CN, Bogduk M. The sacroiliac joint in chronic low back pain. Spine 1995; 20:31-37.

18. Laslett M, Young SB, Aprill CN, McDonald B. Diagnosing painful sacroiliac joints: A validity study of a McKenzie evaluation and sacroiliac provocation tests. Aust $J$ Physiother 2003; 49:89-97.

19. Dreyfuss P, Michaelsen M, Pauza K, McLarty J, Bogduk N. The value of medical history and physical examination in diagnosing sacroiliac joint pain. Spine 1996; 21:25942602.

20. Dreyfuss P, Dryer S, Griffin J, Hoffman J, Walsh N. Positive sacroiliac screening tests in asymptomatic adults. Spine 1994; 19:1138-1143.

21. Merskey H, Bogduk N. Classification of chronic pain. In Merskey H, Bogduk N (eds). Descriptions of Chronic Pain Syndromes and Definition of Pain Terms, $2^{\text {nd }}$ ed. IASP Press, Seattle, 1994:180-181.

22. Vogler JB 3rd, Brown WH, Helms CA, Genant HK. The normal sacroiliac joint: A CT study of asymptomatic patients. Radiology 1984; 151:433-437.

23. Tullberg T, Blomberg S, Branth B, Johnsson R. Manipulation does not alter the position of the sacroiliac joint: A roentgen stereophotogrammatic analysis. Spine 1998; 23:1124-1129.

24. Slipman CW, Sterenfeld EB, Chou LH, Her$\operatorname{zog} R$, Vresilovic $E$. The predictive value of provocative sacroiliac joint stress maneuvers in the diagnosis of sacroiliac joint syndrome. Arch Phys Med Rehab 1998; 79:288-292.

25. Broadhurst NA, Bond MJ. Pain provocation tests for the assessment of sacroiliac joint dysfunction. J Spin Disord 1998; 11: 341-345.

26. Meijne W, van Neerbos K, Aufdemkampe $G$, van der Wurff P. Intraexaminer and interexaminer reliability of the Gillet test. J Man Phys Ther 1999; 22:4-9.

27. Carmichael JP. Inter- and intra- examiner reliability of palpation for sacroiliac joint dysfunction. I Manip Phys Ther 1987; 10: 164-171.

28. Maigne JY, Aivakiklis A, Pfefer F: Results of sacroiliac joint double block and value of sacroiliac pain provocation test in 54 patients with low back pain. Spine 1996; 21: 1889-1892.

29. Ebraheim NA, Mekhail AO, Wiley WF, Jackson WT, Yeasting RA. Radiology of the sacroiliac joint. Spine 1997; 22: 869-876.

30. Resnik CS, Resnick D. Radiology of disorders of the sacroiliac joints. JAMA 1985; 253:2863-2866.

31. Slipman CW, Sterenfeld EB, Chou LH, Her$\operatorname{zog} R$, Vresilovic $E$. The value of radionuclide imaging in the diagnosis of sacroiliac joint syndrome. Spine 1996; 21:22512254. 
32. Maigne JY, Boulahdour H, Charellier G. Value of quantitative radionuclide bone scanning in the diagnosis of sacroiliac joint syndrome in 32 patients with low back pain. Eur Spine Jour 1998; 7: 328-331.

33. Goldberg RP, Genant HK, Shimshak R, Shames D. Applications and limitations of quantitative sacroiliac joint scintigraphy. Radiology 1978; 683-686.

34. Lantto T. The scintigraphy of sacroiliac joints: A comparison of 99-mTc-VPB and 99mTc-MDP. Eur J Nucl Med 1990; 16:677681.

35. Lentle BC, Russell AS, Percy JS, Jackson FI. The scintigraphic investigation of sacroiliac disease. J Nucl Med 1977; 6:529-533.

36. Verlooy H, Mortelmans L, Vleugels S, De Roo M. Quantitative scintigraphy of the sacroiliac joints. Clin Imaging 1992; 16: 230-233.

37. Hanly JG, Mitchell MJ, Barnes DC, MacMillan L. Early recognition of sacroiliitis by magnetic resonance imaging and single photon emission computed tomography. J Rheum 1994; 21:2088-2095.

38. Katz V, Schofferman J, Reynolds J. The sacroiliac joint: a potential cause of pain after lumbar fusion to the sacrum. J Spinal Disord Tech 2003; 16:96-99.

39. West S, King V, Carey T, Lohr K, McKoy N, Sutton S, Lux L. Systems to rate the strength of scientific evidence. Evidence Report/Technology Assessment No. 47 University of North Carolina: Agency for Healthcare Research and Quality. AHRQ Publication No. 02-Eo16; April 2002.

40. Whiting P, Rutjes A, Reitsma J, Bossuyt P, Kleijnen J. The Development of QUADAS: A tools for the quality assessment of studies of diagnostic accuracy included in systematic reviews. BMC Med Res Methodol 2003; 3:25.

41. van Tulder M, Assendelft W, Koes B, Bouter LM. Method guidelines for systematic reviews in the Cochrane Collaboration Back Review Group for Spinal Disorders. Spine 1997; 22:2323-2330.

42. Niemisto L, Kalso E, Malmivaara A, Seitsalo S, Hurri H; Cochrane Collaboration Back Review Group. Radiofrequency denervation for neck and back pain: a systematic review within the framework of the Cochrane collaboration back review group. Spine 2003, 28:1877-1888.

43. Manchikanti L, Staats P, Singh V, Schultz $D$, Vilims B, Jasper J, Kloth D, Trescot A, Hansen H, Falasca T, Racz G, Deer T, Burton A, Helm S, Lou L, Bakhit C, Dunbar E, Atluri S, Calodney A, Hassenbusch S, Feler C. Evidence-based practice guidelines for interventional techniques in the management of chronic spinal pain. Pain Physician 2003; 6:3-80.

44. Manchikanti L, Heavner J, Racz GB, Mekhail NA, Schultz DM, Hansen HC, Singh V. Methods for evidence synthesis in interventional pain management. Pain Physician 2003; 6:89-111.

45. Pang WW, Mok MS, Lin ML, Chang DP, Hwang MH. Application of spinal pain mapping in the diagnosis of low back pain-analysis of 104 cases. Acta Anaesthesiol Sin 1998; 36:71-74.

46. Manchikanti L, Singh V, Pampati V, Damron K, Barnhill R, Beyer C, Cash K. Evaluation of the relative contributions of various structures in chronic low back pain. Pain Physician 2001; 4:308-316.

47. Lord SM, Barnsley L, Bogduk N. The utility of comparative local anesthetic blocks versus placebo-controlled blocks for the diagnosis of cervical zygapophysial joint pain. Clin J Pain. 1995; 11:208-213.

48. Barnsley L, Lord S, Bogduk N. Comparative local anaesthetic blocks in the diagnosis of cervical zygapophysial joint pain. Pain 1993; 55:99-106.

49. Luukkainen RK, Wennerstrand PV, Kautiainen HH, Sanila MT, Asikainen EL.. Efficacy of periarticular corticosteroid treatment of the sacroiliac joint in non-spondylarthropathic patients with chronic low back pain in the region of the sacroiliac joint. Clin Exp Rheumatol 2002; 20:52-54.

50. Maugars Y, Mathis C, Berthelot JM, Charlier C, Prost A. Assessment of the efficacy of sacroiliac corticosteroid injections spondyloarthropathies: a double blind study. BrJ Rheumatol 1996; 35:767-770.

51. Karabacakoglu A, Karakose S, Ozerbil OM, Odev K.. Fluoroscopy-guided intraarticular corticosteroid injection into the sacroiliac joints in patients with ankylosing spondylitis. Acta Radiol 2002; 43: 425-427.
52. Fischer $T$, Biedermann $T$, Hermann KG, Diekmann F, Braun J, Hamm B, Bollow M. Sacroiliitis in children with spondyloarthropathy: therapeutic effect of CT-guided intra-articular corticosteroid injection. Rofo 2003; 175:814-821.

53. Hanly JG, Mitchell M, MacMillan L, Mosher D, Sutton E. Efficacy of sacroiliac corticosteroid injections in patients with inflammatory spondyloarthropathy: Results of a 5 month controlled study. J Rheum 2000; 27:719-722.

54. Slipman CW, Lipetz JS, Plastaras CT, Jackson HB, Vresilovic EJ, Lenrow DA, Braverman DL. Fluoroscopically guided therapeutic sacroiliac joint injections for sacroiliac joint syndrome. Am J Phys Med Rehabil 2001; 80:425-432.

55. Gevargez A, Groenemeyer D, Schirp S, Braun M. CT-guided percutaneous radiofrequency denervation of the sacroiliac joint. Eur Radiol 2002; 12:1260-1365.

56. Ferrante FM, King LF, Roche EA, Kim PS, Aranda M, Delaney LR, Mardini IA, Mannes AJ. Radiofrequency sacroiliac joint denervation for sacroiliac syndrome. Reg Anesth Pain Med 2001; 26:137-142.

57. Yin W, Willard F, Carreiro J, Dreyfuss P. Sensory stimulation-guided sacroiliac joint radiofrequency neurotomy: Technique based on neuroanatomy of the dorsal sacral plexus. Spine 2003; 28:24192425 .

58. Cohen SP, Abdi S. Lateral branch blocks as a treatment for sacroiliac joint pain: A pilot study. Reg Anesth Pain Med 2003; 28: 113-119.

59. Rosenberg JM, Quint TJ, de Rosayro AM. Computerized tomographic localization of clinically-guided sacroiliac joint injections. Clin J Pain 2000; 16:18-21.

6o. Hansen, H. Is Fluoroscopy necessary for sacroiliac joint injections? Pain Physician. 2003; 6:155-158.

61. Goldthwait JE. The lumbo-sacral articulation: an explanation of many cases of "lumbago", "sciatica”, and paraplegia. Boston Med Surg J 1911; 164:365-372.

62. Fortin JD, Vilensky JA, Merkel GJ. Can the sacroiliac joint cause sciatica? Pain Physician 2003; 6:269-271 
